\author{
Alena Kristková \\ Masaryk University \\ kristkovaalena@seznam.cz \\ Pavel Kandalec \\ Masaryk University \\ pavel.kandalec@law.muni.cz
}

\title{
The Principle of Opportunity in the Czech Criminal Procedure Code
}

\author{
Zasada oportunizmu \\ w czeskim Kodeksie postępowania karnego
}

\section{SUMMARY}

This article deals with two principles - the principle of legality and the principle of opportunity which can be seen as contradictory at first sight because only the first mentioned is considered to be a traditional pillar of criminal procedures in continental European countries. The main aim of this article is to emphasize the role of the principle of opportunity in the Czech criminal procedure and to summarize basic institutes which express this principle.

Keywords: legality; opportunity; Czech Criminal Procedure Code

\section{INTRODUCTION}

This article deals with two principles - the principle of legality and the principle of opportunity which can be seen as contradictory at first sight because only the first mentioned is considered to be a traditional pillar of criminal procedures in continental European countries. The main aim of this article is to emphasize the role of the principle of opportunity in the Czech criminal procedure and to summarize basic institutes which express this principle. 


\section{ESSENTIAL PRINCIPLES IN THE CZECH CRIMINAL PROCEDURE}

The authors would like to emphasize that not all the essential principles of the Czech criminal procedure are going to be mentioned in this article but only those which are connected to the topic of this article. But as all the principles of the criminal procedure form an interconnected system, a majority of them is going to be mentioned here.

The system of essential principles of criminal procedure is based on its constitutional basis which is created especially by the Constitution and by the Charter of Fundamental Rights and Freedoms. The system of essential principles has to be understood as a coherent unit where individual principles are linked together and built on each other. The investigative, prosecuting and adjudicating bodies apply these principles proportionally, especially in complicated cases. This means that it is not possible to interpret them as contradictory but on the contrary - they have to be interpreted as complementary. Therefore, it is possible to call them principles rather than rules. The essential principles have to be interpreted in the essence of the Constitution and the Charter of Fundamental Rights and Freedoms. A very specific role plays the provision of the Art. $\S 4$ of the Charter which states that while employing the provisions concerning limitations upon the fundamental rights and freedoms, the essence and significance of these rights and freedoms must be preserved. Such limitations shall not be misused for purposes other than those for which they were enacted. The Criminal Procedure Code (CPC) undoubtedly is a norm providing the mentioned limits.

The supreme principle of the criminal procedure is the principle of due legal process which is regulated in the Art. 2 of the CPC. It is a statutory expression of the provision stipulated in the Art. $8 \S 2$ of the Charter. The essential role of this principle is expressed also by the fact that it is regulated as the first one in the $\mathrm{CPC}$. In the context of the main topic of this article it is necessary to emphasize that in the continental criminal procedures the principle of due process is superior to the principle of the true finding of the facts of the case (material truth). It is not possible to reveal the truth by breaking the law (see the English law of evidence in this context where this principle is not fully established) ${ }^{1}$. Such evidence is inadmissible in court. Revealing the truth is not an absolute value in the democratic states because the criminal procedure is based on the rule of law ${ }^{2}$.

${ }^{1}$ N. Cooper, The Fruit of the Poisoned Tree - the Admissibility of Evidence in Civil Cases, "British German Jurists' Association", p. 2, www.bgja.org.uk/Documents/2011/NigelCooper.pdf [access: 10.11.2015]. On the contrary, the American concept is based on the "fruit of the poisoned tree" which is similar to the European concept of rule of law in evidence law.

${ }^{2}$ In this context see the judgment of the European Court of Human Rights Gäfgen vs. Germany, application No. 22978/05, 30 June 2008. 
Another essential principle is the presumption of innocence. This principle is regulated in the Art. $2 \S 2$ of the CPC, at the constitutional level it is stipulated in the Art. $40 \S 2$ of the Charter and at the international level it is stated in the Art. $6 \S 2$ of the European Convention. This principle is inextricably linked to the principle of material truth because the court verdict on guilt and punishment can be served when all the doubt concerning the guilt of the defendant has been eliminated. In this context the institute of agreement on guilt and punishment gained importance because the European Court of Human Rights (ECHR) stated that not only a judicial decision on guilt and punishment but also a guilty plea shall be considered as a legal finding of truth. Nevertheless, a guilty plea automatically does not have to mean the breaking of the presumption of innocence because this principle is in the disposition of the defendant who can waive this right by pleading guilty ${ }^{3}$. Presumption of innocence is nowadays not only a due process guarantee but also a remedy to protect one's personality and reputation ${ }^{4}$.

The Czech Republic belongs to the system of continental criminal procedure where the principle of legality is the leading concept how to prosecute criminal offences. This principle which says that the public prosecutor is obliged to prosecute all the criminal offences which he gets to know about is statutory regulated in the Art. $2 \S 3$ of the CPC. This principle is linked to the duty of the state bodies to proceed ex officio which expresses the state monopoly on prosecution. The self-help was fully eliminated and the state gained the authority to prosecute all criminal offences during the historical development in the Czech Republic. By this development the private action was taken away but the bill of a recodification of the CPC regulates this institute although foreign experience shows that institutes like private and subsidiary action are not used in practice ${ }^{5}$. This idea to regulate again the private action expresses the overall re-privatizing tendencies of the criminal procedures, which is closely linked to the penetration of the opportunity principle to the continental criminal procedures. According to a research carried out by Jehle and Wade ${ }^{6}$, there is no country in Europe which applies in the pre-trial procedure only a legality principle. There occur some elements of an opportunity principle. Nevertheless, the essential principle of starting the criminal proceedings should be the legality principle in continental Europe. The discretion of a public prosecutor should be limited to minor crimes.

\footnotetext{
${ }^{3}$ Judgment of the European Court of Human Rights Lutz vs. Germany, application No. 9912/82, 25 August 1987.

${ }^{4}$ See the judgment of the European Court of Human Rights Khuzhin and others vs. Russia, application No. 13470/02, 23 October 2008.

${ }^{5}$ See e.g. the commentary to the Austrian regulation in the Austrian CPC: S. Seiler, Strafprozessrecht, 12. überarb. Auflage, Wien 2012, p. 89.

${ }^{6}$ J.M. Jehle, M. Wade, Coping with Overloaded Criminal Justice System, Berlin 2006, p. 27 and following.
} 
The principle of legality is bound to the duty of the state bodies to search for the evidence and to the principle of the material truth because the state bodies have to proceed ex officio while investigating the crime and gathering the evidence. As for the continental criminal procedures, the state bodies have to search for both the liberating and incriminating evidence, which is in contrast to the typical common law division of the criminal case (case for the defence, case for the prosecution), which is called a two-case approach. However, the prosecution has a duty to communicate the evidence in favour of the defence to the party of the defence if the prosecution gains such evidence. Rules regulating the communication between the parties are called disclosure rules ${ }^{7}$.

Another important principle which is connected to the efficiency of criminal procedure and to the penetration of the opportunity principle to the European criminal procedures is the right of the defendant to an adequate length of criminal procedure. The European criminal systems are overloaded and look for ways how to enhance the efficiency of criminal proceedings which is rated by the length of criminal procedure while respecting the rights of the parties at the same time (defendant and the injured party/victims of crime). This requirement is stipulated in Art. $6 \S 1$ of the European Convention, and the ECHR has so far served a big load of judgments on this topic (concerning the Czech Republic as well). According to the Council of Europe Recommendation on simplification of criminal procedure of 1987, there are several ways how to enhance efficiency of criminal proceedings without undermining traditional principles of the continental criminal procedure. The Recommendation aims especially at regulating simplified procedures at minor crimes and regulating some elements of the principle of opportunity (the Recommendation calls it principles of discretionary prosecution). Nowadays there is hardly any jurisdiction in the continental Europe which does not enable the public prosecutor to prosecute minor offenses at his own discretion. There is mostly one specific procedural institute which mirrors the principle of opportunity and it is the discretion of a public prosecutor not to prosecute a minor offense when there is a lack of a public interest. This institute is very common in criminal procedure codes in European countries (e.g. the Czech Republic, Austria, Germany, Slovakia, etc.).

${ }^{7}$ See C. Schuon, International Criminal Procedure. A Clash of Legal Cultures, Hague 2010, p. 15 and following. In England and Wales the public prosecution has a duty to inform the defendant about evidence in favor of the defence since the forties of the $20^{\text {th }}$ century. As the so-called disclosure rules were very extensive and formalized, in 2012, a new version was enacted which is simpler, synoptic and enhances the efficiency of the public prosecution in communication with the defence. In the USA, the disclosure rules are less formalized, the exculpatory evidence has to be handed over on the defence in all cases. For more details see J. Gross, Review of Disclosure in Criminal Proceedings, 2011, www.judiciary.gov.uk/JCO\%2FDocuments\%2FReports\%2Fdisclosure-reviewseptember-2011.pdf [access: 10.11.2015]. 


\section{PRINCIPLE OF LEGALITY AND PRINCIPLE OF OPPORTUNITY - A COMPLICATED RELATIONSHIP}

The principle of opportunity can be characterised as a possibility given to the public prosecutor not to prosecute all the criminal offences which he gets to know about. The public prosecutor can use this possibility in cases where the prosecution would not be useful, effective or even unjust, which would cause that the purpose of the criminal procedure would not be achieved ${ }^{8}$. This concept is often seen as contradictory to the principle of legality which bounds the public prosecutor to prosecute all the offences. The requirement of efficiency of criminal procedure, however, demands regulation of special institutes which would enable the public prosecutor to proceed more flexibly while assessing concrete minor crimes. The criterion whether the public prosecutor should weigh up the use of the principle of opportunity is the criterion of the public interest. The Czech CPC differs among the cases where no public interest is recognizable and where the public interest is weakened and due to this fact the case shall be resolved by using some pre-trial (simplified) procedures, especially diversions.

\section{EFFICIENCY OF CRIMINAL PROCEDURE - A GENERAL PROBLEM}

There are many perspectives, from which the concept of efficiency can be defined; however, a significant view of this category is from the perspective of the length of criminal procedure. The longer the criminal procedure is, the more is the justice weakened (see the legal maxim justice delayed, justice denied). Art. 6 of the European Convention regulates the right to the reasonable length of criminal proceedings which is a part of the right to due process; therefore, there is no due process without the adequate length of criminal procedure. Beyond making the criminal procedure more effective is therefore the idea of shortening the length of criminal procedure and accelerating it and, at the same time, the need to maintain the rights of the defendant and those of the victims, which is definitely not a simple task.

Generally, the criminal justice systems have been hit during the recent decades by increase of petty crime on the one hand, and by emergence of new, more sophisticated, forms of crime (e.g. cybercrime, organized transnational crime,

\footnotetext{
${ }^{8}$ See the division of the motives of regulating opportunity according to the Polish lawyer Cieślak: a procedural and material motive. Procedural motive occurs while prosecuting minor crimes, which often results in inefficiency of criminal procedure because pursuing the whole criminal process with engaging the court does not pay off. On the other hand, the material motive emphasizes the possible injustice of criminal proceedings at minor crimes. See M. Cieślak, Polska procedura karna. Podstawowe zatożenia teoretyczne, Warszawa 1984, p. 292.
} 
etc.) on the other hand. The overall reaction towards this problem can be divided into three groups: increase in staff of criminal justice, decriminalization, alternative dispute resolution (diversions) and regulation of summary procedure at petty crimes $^{9}$. This article is focused on the elements of the opportunity principle which are expressed in the following way:

- discontinuing of criminal procedure due to lack of public interest,

- diversions as a result of a weakened public interest,

- new concept of opportunity in a form of a cooperating witness.

\section{CZECH CRIMINAL PROCEDURE CODE}

\section{Opportunity principle - discontinuing of criminal procedure due to the lack of public interest}

The institute of discontinuing of criminal proceedings on the base of lack of public interest is a very common regulation in continental Europe (see e.g. Austria or Germany). It is connected to the idea that the offenses of a less gravity should not be prosecuted if there is lack of public interest, in the most cases it means that prosecution is not worthy. The Czech Criminal Procedure Code also knows such provisions. A public prosecutor can discontinue a criminal procedure if it is clear that the goal of the criminal procedure was already achieved (in brief - because the facts of the case prove that the committed crime is of a lower gravity than other crimes of this kind). In this context it should be noted that such regulation which eliminates further criminal prosecution of minor crimes when the gravity of the crime is low and the circumstances of the case show that the goal of the prosecution has already been achieved is called a procedural corrective. In contrast to the so-called material corrective, the committed act is really a crime whereas the material corrective applies to the situations when the public prosecutor/police is just assessing whether the committed act was a crime. The procedural corrective is a typical way of handling minor crimes in democratic states where material criminal law is based on the so-called formal concept of a criminal act. This is also the case of the Czech Republic. A very similar regulation can be found in Austria where the public prosecutor has to discontinue the criminal proceedings when circumstances foreseen by law occur ${ }^{10}$. Austrian regulation openly expresses the Roman maxima minima non curat praetor. The Czech CPC does not regulate such an open opportunity as the Austrian one.

\footnotetext{
${ }^{9}$ A. Sotoláŕ, F. Púry, P. Šámal, Alternativni řešeni trestnich věci v praxi, Praha 2000, p. 5.

${ }^{10}$ To analyse this topic in detail see e.g. A. Venier, Einstellung und Anklage im neuen Strafprozessrecht, [in:] 35. Ottensteiner Fortbildungsseminar aus Strafrecht und Kriminologie, Wien 2007.
} 


\section{Opportunity principle - diversions}

The diversions definitely constitute a more simple procedure of achieving justice at minor offenses but, at the same time, they are an expression of a restorative justice concept which prefers rehabilitation of criminals to strict punishing them by the sentence of imprisonment. The Czech CPC distinguishes among the following kinds of diversions ${ }^{11}$ :

- conditional discontinuing of criminal procedure,

- agreement on guilt and punishment.

Conditional discontinuing of criminal procedure. This institute has been effective since 1994. Criminal proceedings can be conditionally discontinued both in the pre-trial stage (by the public prosecutor) and in the trial stage (by judge) of criminal procedure and if the defendant fulfils all the conditions imposed on him, criminal proceedings will be definitely discontinued. The law determines some conditions under which the criminal proceedings can be conditionally discontinued: the perpetrator has to confess to the committed crime and has to pay damages if he inflicted any harm. This diversion is used very often; it is a common way of resolving petty crime. However, the requirement of confession seems to be quite problematic. There are many defendants who feel not guilty and confession causes them a moral dilemma. Inasmuch as the confession is just a formal requirement, there is no need to expose the defendants to such difficulties. It would be better to draw inspiration for example from the Austrian CPC where under such circumstances only consent of the defendant to resolve the case by using this diversion is required.

Agreement on guilt and punishment. This institute is a new kind of diversion which is, however, very controversial and it is debatable if it really fulfils its alleged function - the acceleration of the criminal procedure. The agreement on guilt and punishment was enacted in 2012 after a long debate (at least since the year 2005) concerning the aims and the factual wording of the act. The result is a true hybrid which, in the authors' opinion, does not accelerate the criminal procedure and furthermore weakens some essential principles (e.g. the principle of immediacy, nemo tenetur se ipsum accusare, presumption of innocence, etc.). On the other hand, regulating this institute was a real challenge for the Czech Parliament because such institutes are regulated in many European countries (Slovakia,

${ }^{11}$ Diversions in crimes of juveniles and criminal order are left aside. The settlement between the parties is also left aside because this institute is rather a restorative justice means of resolving a conflict between the parties. This institute does unconditionally not have to accelerate the criminal proceedings because its main function is different and as the practice shows sometimes it takes time before the parties make this agreement. On the other hand, if both parties are willing to settle their dispute like this, there definitely is a possibility to accelerate the procedure. 
Poland, Spain, Italy, etc.) and it appears that these agreements really work and do accelerate the criminal proceedings. However, some jurisdictions avoid regulating it due to a likely conflict with traditional continental principles of criminal procedure (Austria). Germany underwent a long way to regulate this institute and it had been a common practice which, however, did not have a statutory basis ${ }^{12}$. This situation changed in 2009 when the German Parliament enacted the law on agreement on guilt and punishment ${ }^{13}$.

The Czech regulation has just little in common with the Anglo-American guilty plea/plea bargaining. On the base of an agreement on guilt and punishment, minor and medium severe crimes can be resolved, which is a difference between the conditional discontinuing of criminal procedure where only minor crimes can be resolved by using this. The defendant is not entitled to demand to resolve his case by this agreement; it is fully at discretion of the public prosecutor. The defendant has to confess committing the crime in question but, at the same time, the facts of the case must be sufficiently proved and must show that the defendant is highly likely to have committed it. The issue of confession is topical because the duty to confess is a moral dilemma for the defendant who feels innocent; furthermore, the confession cannot be considered as a confessio est regina probationum and because of that it does not seem logical to require such a confession. It is just a formal requirement which could be simply replaced by the Austrian form of consent with resolving the criminal case by diversions - complicity with resolving the case by diversion, the defendant agrees that his case will be resolved by a diversion ${ }^{14}$. If the facts of the case are not sufficiently cleared, it is not possible for the public prosecutor to offer the defendant making an agreement (in spite of the fact that the defendant confessed). This is the first big difference between the typical common law guilty plea. Ambos points out that this kind of approach is really typical for the continental lawyers and it is not obvious only at a national level but also at an international one. Ambos mentions a trial at the ad hoc Court for East Timor where the defendant pled guilty but the panel of judges (a panel created by continental lawyers) examined so thoroughly if his guilty plea had been made voluntarily, consciously and in an unequivocal way that, at the end, the defendant gave up his guilty plea and the trial continued in a standard way. In this context Ambos adds that usually when the continental lawyers want to regulate some common law institutes like guilty plea, they overregulate it, so that such institute

${ }^{12}$ See e.g. J. Musil, Dohody o vině a trestu (Absprachen) v Německu, "Právník" 2008, č. 3, p. 217 and following.

${ }^{13}$ See $\S 257 \mathrm{c}$ of the German Criminal Procedure Code (Strafprozessordnung).

${ }^{14}$ See E.E. Fabrizy, Die österreichische Strafprozessordnung (Strafprozessordnung 1975) mit dem neuen Vorverfahren und den wichtigsten Nebengesetzen. Kurzkommentar, 11. neu bearbeitete Auflage, Wien 2011, p. 491. 
loses its basic function - the acceleration of the criminal proceedings ${ }^{15}$. Another problem is connected, for example, to the charge dismissal practice (common in the USA - the defendant pleads guilty to one offense and the public prosecutor dismisses other charges against him), according to the wording of the statute, such practice is illegal, but it virtually happens and it happened even before the law on agreement on guilt and punishment became effective. As for the role of the judge while approving the agreement on guilt and punishment, it is similar to the role of the common law judge who only acts as a guarantor of the procedural correctness because the Czech judge only checks if the proposal is procedurally correct and does not review the contents of the agreement. By this regulation the principles of immediacy, publicity, of oral proceedings and of free evaluation of evidence are weakened. As for the sentence bargaining, there is no special statutory rate for the defendants who made the agreement on guilt and punishment and furthermore they are not allowed to bargain somehow their punishment. However, if they cooperate with the police and with the public prosecutor, they can await a sentence which is at the lowest statutory rate. This is, however, a general practice. An effective use of this instrument is possible at crimes (statutory rate higher than 5 years of imprisonment) because other diversions can be used only at minor crimes. To sum up, this institute seems to be quite useless but, on the other hand, it is quite early to draw some premature conclusions as this act has been effective only one year and a half.

\section{COOPERATING WITNESS}

This institute is a typical instrument of a new pragmatic use of opportunity ${ }^{16}$. Weigend states that the increase in complicated organized crime and difficulties in obtaining evidence induced the situation that the state bodies resigned to fulfil the essential purpose of criminal procedure and chose to trade with justice by using the institute of a crown witness.

A cooperating witness, the Czech form of the crown witness, serves for simpler revealing of organized crime where in many cases the facts of the case cannot be revealed by other means than by using somebody from the inside of such an organized group. These people who are perpetrators of serious crime but who are, at the same time, willing to cooperate with the police are called cooperating witnesses. It is definitely debatable if this approach is correct but it is justifiable because two interests are weighed up - the interest in revealing and punishing members of an organized group which will not be able to commit serious crime

${ }^{15}$ See K. Ambos, International Criminal Procedure - Adversarial, Inquisitorial or Mixed?, "International Criminal Law Review” 2003, No. 3, p. 18.

${ }^{16}$ See T. Weigend, Das „Opportunitätstprinzip“ Zwischen Einzelfallgerechtigkeit und Systemeffizienz, „Zeitschrift für die Gesamte Strafrechtswissenschaft” 1997, p. 108 and following. 
anymore and the interest in punishing one single member of this group who is, however, willing to help to reveal a group of which he is a member. It is a dilemma but usually the interest in destroying an organized group prevails. Furthermore, such cooperating witnesses must fulfil other conditions such as not committing a crime of murder or a sexual crime while being a member of the organized group (see the Austrian and Czech regulation).

In the context of the discussed topic the institute of collaborating witness is interesting because of the potential to accelerate the criminal proceedings by revealing the evidence by this witness, which consequently enables the police to proceed faster. The Czech regulation unfortunately has not a very big potential to accelerate the proceedings but recently there have been some amendments which enhanced its possibilities.

The cooperating witness has been regulated since 2010. This institute is not unfamiliar to many European countries (it is regulated in Germany, Austria, Italy, Poland, etc.). The original wording of the law did not have much potential to make the criminal procedure more efficient. Firstly, the defendant had to fulfil many conditions to be labelled in the indictment by the public prosecutor as a cooperating witness. Furthermore, this labelling was fully at the discretion of the public prosecutor and it could easily happen that the defendant fulfilled all the statutory conditions (confession, reporting essential facts able to reveal crimes being committed by an organized group and more) but in spite of this fact he was not labelled as a cooperating witness in the indictment. Secondly, the court was not obliged to reduce the penalty of such witness, this was also fully at the court's discretion. As a result, this institute was hardly used because it was extremely disadvantageous for the defendant to expose himself to a dangerous situation when the prospective benefits were unsure. In this context it is good to mention that a very similar regulation was effective (but obsolete) in Austria ${ }^{17}$ and it is incomprehensible why the Czech Parliament enacted such law which was doomed to failure from the very beginning.

Consequently, due to the factual uselessness there was enacted an amendment to the CPC concerning cooperating witness. This amendment regulated a possible impunity of the cooperating witness if he fulfils a few strict conditions. If he does so, the court must not impose a punishment on the cooperating witness. The difference is then that the court is obliged (it is not at its discretion anymore) to waive the punishment or to mitigate the punishment of the cooperating witness. However, this procedure is connected to the trial. The pre-trial procedure is still the same, it means that it is still fully at the discretion of the public prosecutor to label the defendant as a cooperating witness in the indictment or not. The practical

\footnotetext{
${ }^{17}$ See $\S 41$ a of the Austrian Criminal Procedure Code, Act No. 1975/631 Coll.
} 
use of this amendment cannot be properly evaluated now as it has been effective since 2012 .

The Czech Parliament could, however, draw its inspiration from the Austrian Criminal Procedure Code where the cases of the cooperating witnesses can be resolved fully during the pre-trial procedure on the base of a decision of a public prosecutor as a kind of diversion when the criminal proceedings against a cooperating witness is conditionally discontinued ${ }^{18}$. A very similar regulation exists also in Slovakia where it is possible to discontinue the prosecution of a cooperating witness in a pre-trial procedure as well ${ }^{19}$. This institute is also regulated in Germany, Italy or Poland ${ }^{20}$.

\section{CONCLUSION}

Penetration of the common law elements into the continental European criminal procedures is a trend which is closely connected to the issue of efficiency of criminal procedure as such. The Czech criminal procedure is not an exception in this process. An integral part of this process is also a debate concerning the nature of continental criminal procedure, especially the essential principles and their possible erosion. However, the principle of opportunity provides an effective possibility how to deal with overloaded justice. Based on this fact, the principle of opportunity should be considered as a complementary principle to the principle of legality.

\section{BIBLIOGRAPHY}

Ambos K., International Criminal Procedure - Adversarial, Inquisitorial or Mixed?, "International Criminal Law Review” 2003, No. 3.

Cieślak M., Polska procedura karna. Podstawowe założenia teoretyczne, Warszawa 1984.

Cooper N., The Fruit of the Poisoned Tree - the Admissibility of Evidence in Civil Cases, "British German Jurists' Association”, www.bgja.org.uk/Documents/2011/NigelCooper.pdf [access: 10.11.2015].

Fabrizy E.E., Die österreichische Strafprozessordnung (Strafprozessordnung 1975) mit dem neuen Vorverfahren und den wichtigsten Nebengesetzen. Kurzkommentar, 11. neu bearbeitete Auflage, Wien 2011.

Gross J., Review of Disclosure in Criminal Proceedings, 2011, www.judiciary.gov.uk/JCO\%2FDocu ments\%2FReports\%2Fdisclosure-review-september-2011.pdf [access: 10.11.2015].

Jehle J.M., Wade M., Coping with Overloaded Criminal Justice System, Berlin 2006.

Mirtl A., Straffrei dank neuer Kronzeugenregelung?, www.wirtschaftsanwaelte.at/straffrei-dankneuer-kronzeugenregelung-2 [access: 10.11.2015].

Musil J., Dohody o vině a trestu (Absprachen) v Německu, "Právník“ 2008.

${ }^{18}$ For details see A. Mirtl, Straffrei dank neuer Kronzeugenregelung?, www.wirtschaftsanwaelte.at/straffrei-dank-neuer-kronzeugenregelung-2 [access: 10.11.2015].

${ }^{19}$ See $\S 218$ of the Slovakian Criminal Procedure Code, Act No. 301/2005 Coll.

${ }^{20}$ See J. Musil, Korunní svědek - ano či ne?, "Trestní Právo“ 2003, No. 4, p. 21. 
Pobrane z czasopisma Studia Iuridica Lublinensia http://studiaiuridica.umes.pl Data: 26/04/2023 12:56:28

Alena Kristková, Pavel Kandalec

Musil J., Korunní svědek - ano či ne?, "Trestní Právo" 2003, No. 4.

Schuon C., International Criminal Procedure. A Clash of Legal Cultures, Hague 2010.

Seiler S., Strafprozessrecht, 12. überarb. Auflage, Wien 2012.

Sotolář A., Púry F., Šámal P., Alternativní řešeni trestnich věcí v praxi, Praha 2000.

Venier A., Einstellung und Anklage im neuen Strafprozessrecht, [in:] 35. Ottensteiner Fortbildungsseminar aus Strafrecht und Kriminologie, Wien 2007.

Weigend T., Das „Opportunitätstprinzip“ Zwischen Einzelfallgerechtigkeit und Systemeffizienz, „Zeitschrift für die Gesamte Strafrechtswissenschaft” 1997.

Judgment of the European Court of Human Rights Gäfgen vs. Germany, application No. 22978/05, 30 June 2008.

Judgment of the European Court of Human Rights Lutz vs. Germany, application No. 9912/82, 25 August 1987.

Judgment of the European Court of Human Rights Khuzhin and others vs. Russia, application No. 13470/02, 23 October 2008.

\section{STRESZCZENIE}

Artykuł dotyczy dwóch zasad - zasady legalizmu oraz zasady oportunizmu, które na pierwszy rzut oka mogą być postrzegane jako sprzeczne, ponieważ jedynie pierwsza $\mathrm{z}$ nich jest uważana za tradycyjny filar postępowania karnego w państwach Europy kontynentalnej. Celem niniejszego opracowania jest podkreślenie roli, jaką pełni zasada oportunizmu w procedurach postępowania karnego w Czechach oraz przedstawienie głównych instytucji, które wyrażają tę zasadę.

Słowa kluczowe: legalizm; oportunizm; czeski Kodeks postępowania karnego 